\title{
STUDIES ON POLIOMYELITIS VIRUS
}

\section{THE USE OF ULTRA-VIOLET LIGHT AS AN ADDITIONAL MEANS OF INACTIVATION OF FORMALINIZED VACCINE}

\author{
BY J. W. F. HAMPTON AND A. POLSON \\ Laboratories of the Poliomyelitis Research Foundation, Johannesburg, and the \\ Council for Scientific and Industrial Research and University of Capetown Virus \\ Research Unit, University of Capetown
}

(With 1 Figure in the Text)

\section{INTRODUCTION}

The nature of the inactivation of poliomyelitis virus by formaldehyde is such that detection of the point of complete inactivation is difficult. The subsequent testing of an inactivated virus suspension for the presence of traces of live virus is an elaborate procedure requiring highly skilled staff. The occasional failure of the inactivation process employed is an indication that a careful balance must be struck between the amount of formaldehyde required for complete inactivation of virus and the maximum amount permitted if antigenicity is to be preserved. The margin of safety has been estimated by Gard (1955).

While ultra-violet light has not yet been used as the sole inactivating agent in producing poliomyelitis vaccine, its use as an aid in improving the safety of formaldehyde inactivated vaccine is reported here.

\section{MATERIALS AND METHODS}

(a) Virus suspensions

Tissue-culture harvests such as are used in the production of polio vaccine were used. These were filtered through a coarse Seitz pad followed by two passes through ultra-fine (no. 5 porosity) sintered-glass filters, but were not further purified. The strains used were: Type 1, Brunhilde-Enders-Chimp K.P. 4; Type 2, Cincinnati F.A.F. 117, K.P. 27; Type 3, Leon K.P. 35 of Sabin.

\section{(b) Virus assay}

This was carried out in the usual manner in roller-tube cultures of trypsinized monkey-kidney cells. In some experiments the colour-change method of Salk, Youngner \& Ward (1954) was used; this has been found to be quite satisfactory with lactalbumen hydrolysate medium and monkey-kidney cells and has enabled more work to be accomplished with limited facilities. All titres are given as T.C.I.D. ${ }_{50} / \mathrm{ml}$.

\section{(c) Source of ultra-violet light}

The failure of light filtered by means of the method of Kasha (1948) from a 'Hanovia' lamp (The General Electric Co. Wembley) to kill virus in a previous experiment (Hampton, Polson \& Selzer, 1958) led us to an investigation of various. 
types of ultra-violet lamps commonly available. Use was made of a partially dismantled spectro-photometer as a means of measuring the relative strengths of the various bands emitted. By this means more than $90 \%$ of the ultra-violet emission of the 'Sterilamp' (The Westinghouse Electric and Manufacturing Company) was found to be in the $253.5 \mathrm{~m} \mu$ mercury line. This being virtually a monochromatic source, it was chosen for these experiments as it obviated the need for any elaborate apparatus as a source of ultra-violet light.

\section{(d) Method of irradiation}

As a necessary preliminary to these studies the rates of inactivation of the virus strains currently being used had to be determined before any quantitative inactivating dose of ultra-violet light could be given to formalinized vaccine. The apparatus used consisted of a Petri dish rocking at $78 / \mathrm{min}$., situated $7.0 \mathrm{~cm}$. from a WL 15 (G. 30, T.8) Sterilamp. The depth of virus fluid in the Petri dish was $3 \cdot 0 \mathrm{~mm}$. Small aliquots were taken at various intervals during irradiation and titrated. The emission of the lamp was measured by means of a Westinghouse SM 600 photoelectric meter, and was maintained at between 77.5 and $85 \mu \mathrm{W} . / \mathrm{cm} .^{2}$ at $1 \mathrm{~m}$.

\section{(e) Antigenicity tests}

The method described by Gard, Wesslen, Fagraeus, Svedmyr \& Olin (1956) was used with the following modifications : adult guinea-pigs were used and each animal received four intradermal doses of $0.2 \mathrm{ml}$. at intervals of 14, 8 and 9 days. Blood was taken by heart puncture 7 days after the last inoculation. Sera were tested in vitro by the colour change method of Salk, Youngner \& Ward (1954) after inactivation at $56^{\circ} \mathrm{C}$. Sera were diluted $1: 5$ and the strength of test virus was titrated at the same time as the neutralizing test.

\section{RESULTS}

(a) Inactivation rates of virus

In all cases, and after replicate tests, similar rates of inactivation were found. This applied to Types 1-3 viruses and to a Type 1 virus which had 'broken through' in a vaccine safety test and is referred to as 'formalin survivor'. In no case was any evidence found to show that the inactivation curve was other than a straight line, as has been described by Fogh (1955), and later by Taylor, Kay, McLean, Oppenheimer \& Stimpert (1957) nor were any signs of interference phenomena detected. The relative rates of inactivation in this apparatus are given in Table 1, where they are expressed as the number of seconds irradiation required to lower the titre of remaining live virus by $90 \%$ or one logarithm.

Table 1. Relative inactivation rates (number of seconds irradiation per log inactivation) of unpurified suspension

$\begin{array}{lr}\text { Type 1 } & 9 \cdot 5 \\ \text { Type 2 } & 14 \cdot 1 \\ \text { Type 3 } & 11 \cdot 5 \\ \text { 'Formalin survivor' } & 13 \cdot 2\end{array}$


Other experiments were carried out which showed that, under these conditions, the depth of fluid, the concentration of virus or of impurity affected only the speed and not the linearity of inactivation. This is to be expected with this type of inactivation process (see Lea, 1955).

\section{(b) Irradiation of vaccine}

In order to irradiate continuously large amounts of vaccine, a simple irradiator was used which is illustrated in Fig. 1. This consists of a tightly wound coil, $9.5 \mathrm{~cm}$. diameter and about $20 \mathrm{~cm}$. long, of clear quartz tubing (The Thermal Syndicate Ltd., 14 Old Pye Street, London, S.W. 1) surrounding a Sterilamp. The tubing is

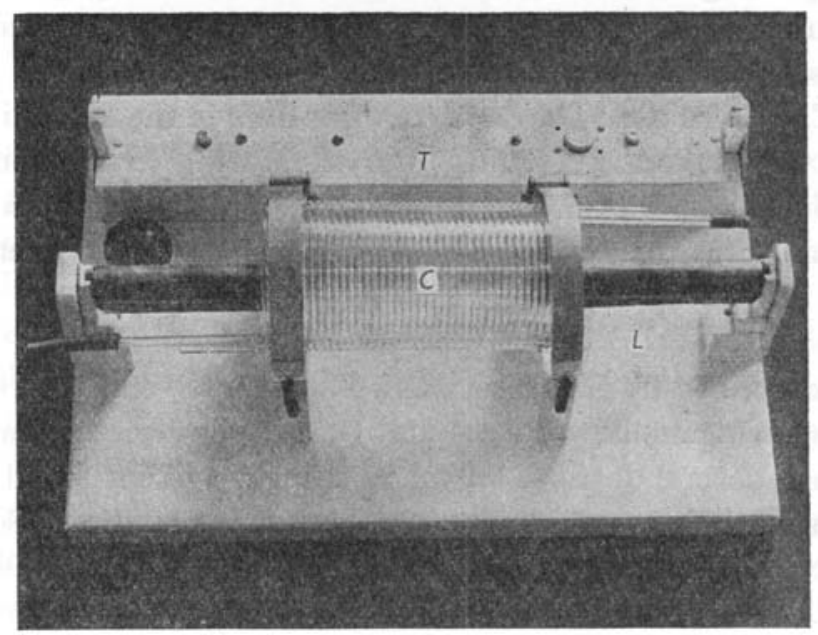

Fig. 1. Continuous flow irradiator of clear quartz tubing. $C$, coil; $L$, lamp with metal masks in position; $T$, channel for testing lamp prior to use. The apparatus is shielded by a metal cover while in use.

3-4 mm. internal diameter. The dose of ultra-violet radiation to which the material is subjected can be varied by changing the rate of flow through the coil and also by masking the lamp to leave different lengths of it exposed. At no time is the virus suspension exposed to the air and the apparatus is easily dismantled so that all parts coming in contact with vaccine can be autoclaved. It was used in series with a simple all-glass flowmeter. A further advantage of this apparatus is that it causes little or no temperature rise. It has also been used successfully for sterilizing tissue-culture medium.

The virucidal power of this irradiator was determined by passing virus through it at different rates and with different lengths of lamp exposed. It was found togive linear inactivation rates corresponding to approximately $3 \cdot 6$ sec. exposure per log of virus inactivated. At the maximum rate of flow which we could obtain, $320 \mathrm{ml} . / \mathrm{min}$., and with $\mathbf{5 \cdot 6} \mathrm{cm}$. of lamp exposed, $90 \%$ of the virus was inactivated, while at a flow rate of $200 \mathrm{ml} . / \mathrm{min}$. with $18 \mathrm{~cm}$. of lamp exposed, the concentration of live virus was lowered by $10^{6}$. Thus the dose of ultra-violet light may be varied to suit the material being inactivated. 
An inactivation dose capable of reducing the titre by $10^{3}$ was decided upon for the irradiation of formalinized vaccine, as this would reduce the chances of live virus surviving by about a 1000 -fold. Accordingly, samples of formalinized vaccine were thus irradiated and their antigenicity determined. These are shown in Table 2.

As we had found previously (Hampton, Polson \& Selzer, 1958) and as has also been shown by Kelly \& Dalldorf (1956), the titre of virus used in the neutralization test is of considerable importance in assaying the neutralizing power of sera. Unfortunately, we were unable to test all the sera simultaneously against the same dose of test virus.

Table 2. The antigenic potency of formalinized vaccine after ultra-violet irradiation sufficient to inactivate $10^{3}$ T.C.I.D. ${ }_{50}$ of virus. The titre of test virus is given in brackets

\begin{tabular}{ccrrr} 
Sample & Dilution of & \multicolumn{2}{c}{$\%$ of sera protective } \\
antigen & Type 1 & Type 2 & Type 3 \\
Sample 1 & Undiluted & $100\left(10^{-2 \cdot 8}\right)$ & $100\left(10^{-0.5}\right)$ & $0\left(10^{-0.5}\right)$ \\
Before irradiation & $1: 10$ & $0\left(10^{-2 \cdot 8}\right)$ & $66\left(10^{-0.5}\right)$ & $0\left(10^{-0.5}\right)$ \\
Sample 1 & Undiluted & $100\left(10^{-1 \cdot 5}\right)$ & $100\left(10^{-0.8}\right)$ & $10\left(1.0^{-1 \cdot 3}\right)$ \\
After irradiation & $1: 10$ & $0\left(10^{-1 \cdot 5}\right)$ & $36\left(10^{-0.8}\right)$ & $25\left(10^{-1 \cdot 3}\right)$ \\
Sample 2 & Undiluted & $64\left(10^{-1 \cdot 2}\right)$ & $23\left(10^{-1 \cdot 4}\right)$ & $0\left(10^{-0.7}\right)$ \\
After irradiation & $1: 10$ & $0\left(10^{-1 \cdot 2}\right)$ & $0\left(10^{-1 \cdot 4}\right)$ & $0\left(10^{-0.7}\right)$
\end{tabular}

The results obtained showed that the antigenic potency of the vaccine was not markedly affected. A further sample, similarly inoculated, but in which the immune sera were tested by roller-tube culture against an estimated 100 T.C.I.D. ${ }_{50}$ of virus, was also shown to have retained its potency. The anomaly shown with sample 1, where the serum antibody against Type 3 appeared to be greater after irradiation than before has been encountered in other experiments and is being investigated.

A small batch of $8 \mathrm{l}$. of vaccine was next treated with the same amount of irradiation. As this proved successful further large batches of routinely produced vaccine were irradiated and these batches have all met with the regulation safety and potency requirements.

\section{DISCUSSION}

That the rate of virus inactivation by ultra-violet light can be shown to be linear with the use of simple apparatus and relatively crude virus suspensions has been previously demonstrated (McLaren, 1949) though contradicted by others (Taylor, Sharp, Beard, Finkelstein \& Beard (1941), and Taylor, Kay, Timm, McLean, Oppenheimer \& Stimpert (1956)). The present work was undertaken to determine if it was possible to subject a vaccine to a known inactivating dose of ultra-violet without damaging its antigenicity, and also to find out to what extent this amount of irradiation would lower the chances of survival of live virus. Much of the work presented on this subject in the past has lacked this quantitative aspect and material was simply stated to have been 'irradiated sufficiently to kill all the virus'. Investigation of the immunizing potency of virus suspensions killed by known 
overdoses of ultra-violet light alone are at present being carried out, but the work described here has shown that when a virus suspension which has been inactivated by formaldehyde and probably contains no live virus is subjected to a second method of inactivation which would kill $99.9 \%$ of the virus present in a similar suspension of living virus, the antigenic potency is little affected, if at all. It is also of interest that irradiation of very thin films in expensive and complicated apparatus was not necessary for the preservation of antigenicity.

The validity and accuracy of the test used to determine antigenic potency leaves much to be desired, but this test has been shown to be of value, by Gard et al. (1956) and Kelly \& Dalldorf (1956), and is relatively cheaply and easily carried out. It is not unreasonable to expect, however, that if an antigen can provoke antibody in a non-susceptible animal then it is likely to produce more rather than less response in a susceptible animal.

\section{SUMMARY}

The inactivation rates of tissue-culture polio virus have been determined and these have been applied to the irradiation of formalinized vaccine, as an additional inactivation process, using a simple irradiator.

The antigenic potency of the vaccine was apparently unimpaired.

We wish to thank the late Prof. van den Ende for his keen interest and criticism; Dr H. Malherbe and his staff for carrying out many of the titrations; Dr P. D. Winter for co-operation in irradiating samples of vaccine, and Margaret Pakes for invaluable technical assistance.

\section{REFERENCES}

Fogh, J. (1955). Proc. Soc. exp. Biol., N.Y., 89, 464.

GARD, S. (1955). European Association Against Polio. 3rd Symposium.

Gard, S., Wesslen, T., Fagraeus, A., Svedmyr, A. \& Olin, G. (1956). Arch. ges. Virusforsch. 6, 401 .

Hampton, J. W. F., Polson, A. \& Selzer, Golda (1958). J. Hyg., Camb., 56, 260.

KASHA, M. (1948). J. opt. Soc. Amer. 38, 929.

Kally, S. \& Dalldorf, G. (1956). Amer. J. Hyg. 64, 243.

LEA, D. E. (1955). Actions of Radiations on Living Cells, 2nd ed. Cambridge University Press. McLaren, A. D. (1949). Advanc. Enzymol. 9, 75.

Salk, J. E., Youngner, J. S. \& Ward, E. N. (1954). Amer. J. Hyg. 60, 214.

Taylor, A. R., Kay, W. W., Mclean, Y. W., Oppenheimer, F. \& Stimpert, F. D. (1957). J. Immunol. 78, 45.

Taylor, A. R., Kay, W. W., Trmm, E. A., Mclean, I. W., Oppenheimer, F. \& Stimpert, F.D. (1956). Fed. Proc. 15, 617.

Taylor, A. R., Sharp, D. G., Beard, D., Finkelstein, H. \& Beard, J. W. (1941). J. infect. Dis. 59, 224.

(MS. received for publication 29. x. 57) 